\title{
Production and Commercialization of Helianthus annuus L. for Cut Flowers in Texcoco, Mexico
}

\begin{abstract}
García-Reyes, V. ${ }^{1}$; Silvano-Sánchez, J. ${ }^{2}$; Zavala-Ruiz, J. ${ }^{3}$; Meraz-Huescas, L. ${ }^{1}$; Baltazar-Bernal, O. ${ }^{*}$
${ }^{1}$ Colegio de Postgraduados Campus Montecillo. Carretera México-Texcoco. Km. 36.5, Montecillo, México. ${ }^{2}$ Colegio de Posgraduados Campus Campeche, Carretera Haltunchén-Edzná km 17.5, Sihochac, municipio de Champotón, Campeche. ${ }^{3}$ Universidad Autónoma Metropolitana, Prolongación Canal de Miramontes 3855, Col. Ex-Hacienda San Juan de Dios, Alcaldía de Tlalpan, Ciudad de México. ${ }^{4}$ Colegio de Postgraduados Campus Córdoba. Carretera Federal CórdobaVeracruz. Km 348. Congregación Manuel León, Municipio de Amatlán de los Reyes, Veracruz, México. C. P. 94946.
\end{abstract}

*Corresponding author: obduliabbacolpos.mx

\section{ABSTRACT}

Objective: To evaluate the process of sunflower production (Helianthus annuus L.) for fresh cutting flowers, considering two sowing dates, growing degree-days, and commercialization.

Design/Methodology/Approach: A completely randomized experimental design with subsampling was used, with five repetitions per treatment (sowing date), in order to analyze the variables: number of leaves, height, and flower diameter. Vincent Choice Dark Eye BallTM sunflowers seeds were sown in black plastic boxes with $8 \mathrm{~cm}$ of soil on January 31 and February 11, 2020, at 153 plants per $\mathrm{m}^{-2}$ in a greenhouse. Later, the seedlings were grown in the open field until harvesting, after which they were given added value and then locally traded. In addition, the growing degree-days (GDD) were calculated.

Results: The sunflowers registered a height of $55 \mathrm{~cm}, 13$ leaves per stalk, and a flower diameter of $6.88 \mathrm{~cm}$. Late sowing favored the height and diameter of the flower. The sunflower hybrid required more GDD to reach commercial flower maturity in the first sowing date. The cost-benefit ratio was 1.38

Study Limitations/Implications: Seeds were sown on only two dates.

Findings/Conclusions: The production process involved planning, management, and commercialization. The sunflower hybrid required on average 499 GDD to reach the cutting point. The added value increased the price fivefold.

Key words: floriculture, productive process, sunflower, added value.

\section{INTRODUCTION}

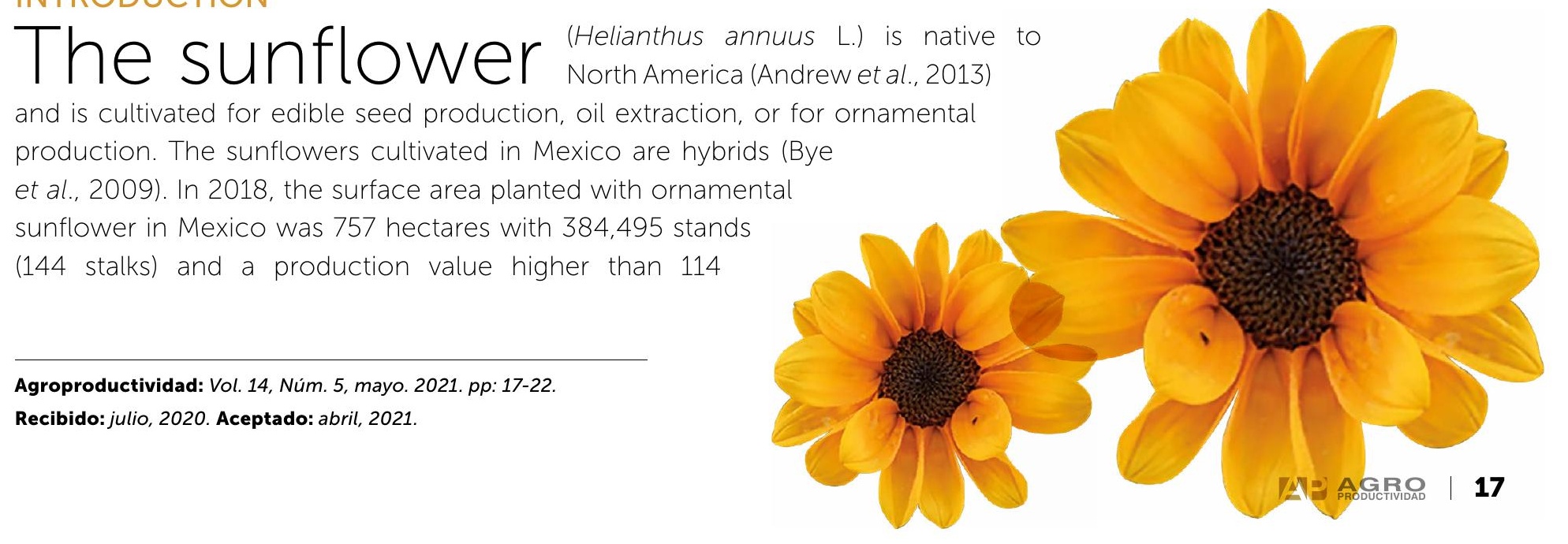


million pesos (SIAP, 2018). The production of ornamental sunflower occurs in the states of Baja California, Estado de México, Morelos, Puebla, and Sonora; however, this crop has high production potential in other states in the country, due its capacity to adapt to diverse climates. At a temperature lower than $4{ }^{\circ} \mathrm{C}$, sunflower does not germinate, and therefore in temperate regions it is germinated in greenhouses (Alba and Llanos, 1990). Different sowing dates can cause differences during the development stages of the crop due to ambient temperatures (Baghdadi et al., 2014). Sunflower hybrids require a different amount growing degree-days (GDD) for each of the phenological stages. The most commonly used
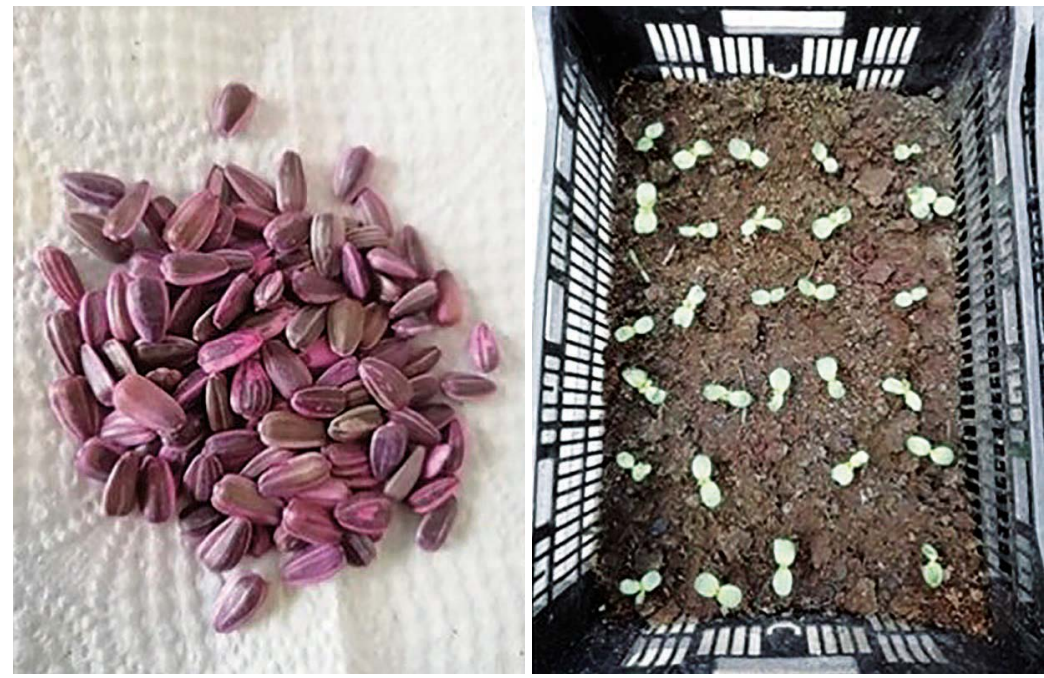

Figure 1. Sunflower seeds and seedlings in black plastic boxes. temperature index to estimate the plant's development is the GDD and its accumulation allows for determining the maturity of the plant (Qadir et al., 2007). The ornamental sunflower can be sown at densities of 60 plants per $\mathrm{m}^{-2}$ while preserving their commercial quality (VeraMontenegro and Chavarría, 2010). In this study some variables of the cutting sunflower crop are reported, cultivated in the open field considering two sowing dates, GDD, and commercialization.

\section{MATERIALS AND METHODOLOGY}

The study was conducted outdoors in the Montecillo Campus of Colegio de Postgraduados, in Montecillo, Texcoco, Estado de México $\left(19.52^{\circ} \mathrm{N}, 98.88^{\circ} \mathrm{W}\right.$ at an altitude of $2,250 \mathrm{~m}$ ). The climate is subhumid temperate with summer rains. The average annual temperature is $14.6{ }^{\circ} \mathrm{C}$ and the precipitation is $558.5 \mathrm{~mm}$ (Escalante-Estrada et al., 2015). Germination occurred in a gable-type greenhouse with lateral anti-trip mesh netting.

\section{Germination stage}

The Vincent Choice Dark Eye BallTM seeds, resistant to low temperatures, were sown in 8 $\mathrm{cm}$ of 1:1 peat moss substrate
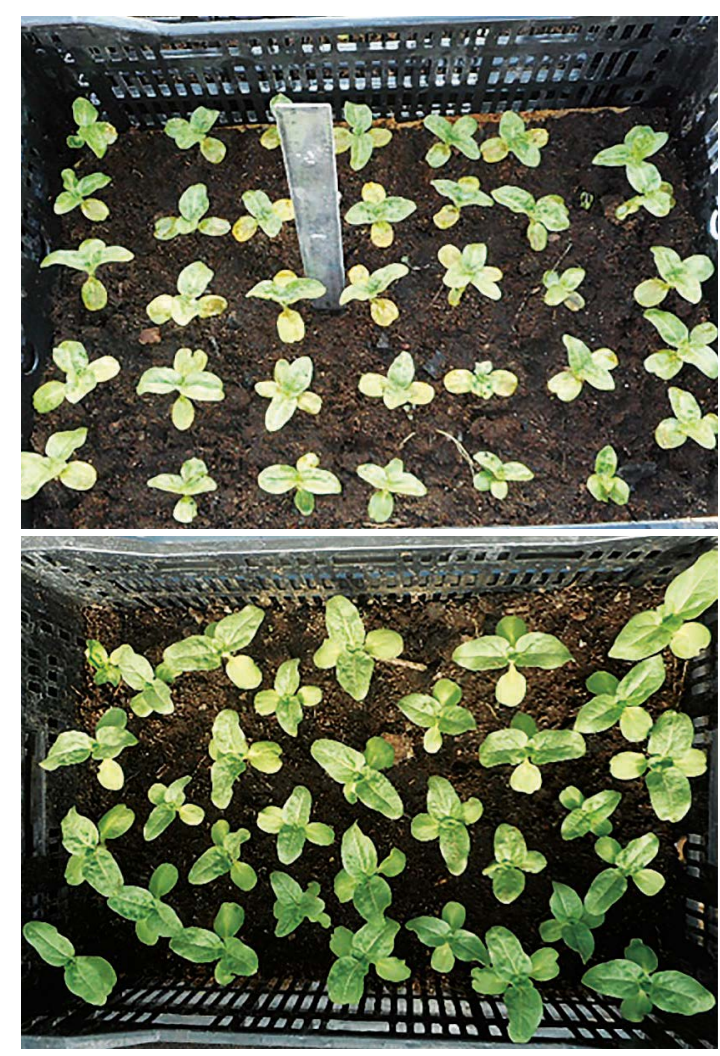

Figure 2. Sunflower seedlings of 10 days (up) and 21 days (down) germinated in the greenhouse and placed outdoors. and hill soil within black $57 \mathrm{~cm}$ long $\times 36.5 \mathrm{~cm}$ wide $\times$ $22.5 \mathrm{~cm}$ high plastic boxes. The bottom was covered in newspaper to avoid loss of substrate (Figure 1).

Sowing took place on January 31 and February 11, at a depth of $2.5 \mathrm{~cm}$ with a planting density of 153 plants per $\mathrm{m}^{-2}$, and substrate humidity was maintained at field capacity with manual irrigation. The experiment was conducted in a completely randomized design (CRD), with five repetitions per treatment, sowing date, to analyze the variables of number of leaves, height, and flower diameter. The data were analyzed as a CRD with subsampling (Zamudio and Alvarado, 1994), using the statistical software SAS (v. 9.3, SAS Institute, Inc). The multiple means comparison test was done with Tukey's method with a significance level of $5 \%$.

\section{Vegetative stage in the open field}

Temperature influences the development of sunflower, so the seedlings were transplanted to the field once the daily minimum temperature was above $7^{\circ} \mathrm{C}$ (Figure 2). The first transfer date was at 21 days, and the second date with seedlings at 10 days after sowing (DAS), 
under integral pest and disease management. At 10 DAS, weekly fertilizer use began, using a foliar fertilizer with $\mathrm{N} 11 \%, \mathrm{P} 8 \%, \mathrm{~K} 6 \%$, and micronutrients at a dosage of $20 \mathrm{~mL}$ in $10 \mathrm{~L}$ of water. After a month, triple 18 was applied (18N-18P-18K) at a dosage of $1 \mathrm{~kg} \mathrm{ha}^{-1}$ in the weekly irrigation.

\section{Harvesting stage}

Ninety-eight percent (98\%) of germinated seeds produced a commercial-quality flower for cutting. Harvesting occurred at 62 days for the first sowing date and 54 days for the second sowing. Daily temperature readings from the agrometeorological station in Colegio de Postgraduados were registered and used, and a base temperature (Tb) of $6.6^{\circ} \mathrm{C}$ was used as suggested by Hammer et al. (1982) to calculate GDD for each development stage, as per the visual scale proposed by Schneiter and Miller (1981). The GDD were calculated with the methodology proposed by the University of California (2017), adding up the daily values of mean temperature that were above the $\mathrm{Tb}\left(6.6^{\circ} \mathrm{C}\right)$ using the following equation:

$$
G D D=\frac{T_{\max }+T_{\min }}{2}-T b
$$

\section{RESULTS AND DISCUSSION}

Plant height and flower diameter were significantly greater in the sunflowers sowed on February 11, and although this species has ample climate adaptability (Balalić et al., 2012), the hybrid was affected by temperature (Baghdadi et al., 2014) in the first sowing. This coincides with that reported by Da Silva et al. (2018) in six cultivars of ornamental sunflower sown in the warm season; they showed an increase of $20.3 \%, 26.1 \%, 16.8 \%$, and $18.6 \%$ in plant height, stalk diameter, number of leaves, and diameter of internal inflorescence, respectively, compared to the winter sowing (Table 1).

\section{Growing degree-days}

The Vincent Choice Dark Eye sunflower hybrid required 523 GDD to reach commercial maturity in the flower for the sowing date of January 31, and 476 GDD for the date of February 11 (Figure 3). The plants from both sowing dates showed slight variations in the GDD that were required for their development. Qadir et al. (2007) report that, under certain climate conditions, early sowings
Table 1. Plant height, flower diameter and number of leaves of sunflower 'Vincent Choice Dark Eye' for cut flower on two sowing dates.

\begin{tabular}{c|c|c|c} 
Sowign date & $\begin{array}{c}\text { Plant height } \\
(\mathrm{cm})\end{array}$ & $\begin{array}{c}\text { Flower diameter } \\
(\mathrm{cm})\end{array}$ & $\begin{array}{c}\text { Number } \\
\text { leaves }\end{array}$ \\
\hline January 31 & $47.84 \mathrm{~b}^{*}$ & $6.091 \mathrm{~b}$ & $13.69 \mathrm{a}$ \\
\hline February 11 & $54.99 \mathrm{a}$ & $8.013 \mathrm{a}$ & $12.8 \mathrm{a}$ \\
\hline SE & 11.62 & 1.42 & 3.90 \\
\hline
\end{tabular}

$\mathrm{SE}=$ Standard error. ${ }^{*}$ The means of the columns followed by different letters are statistically different (Tukey, $\mathrm{p} \leq 0.05$ ).

require more GDD when compared to the sowing windows that are used in the area.

The cultivation cycle of ornamental sunflower was 62 days to reach commercial maturity for the sowing date of January 31, and 54 days for the second sowing date. According to Alberio et al. (2015), this is because later sowing dates accelerate the crop's development because higher temperatures occur during the vegetative stage (Table 2). The data from the calculated GDD serve as a reference for scheduling sowing dates of the Vincent Choice Dark Eye sunflower hybrid, under conditions similar to those described in this study.

\section{Pest control}

Sunflower cultivation resulted in few weeds; however, pests such as the whitefly (Bemisia tabaco, Figure 4a),

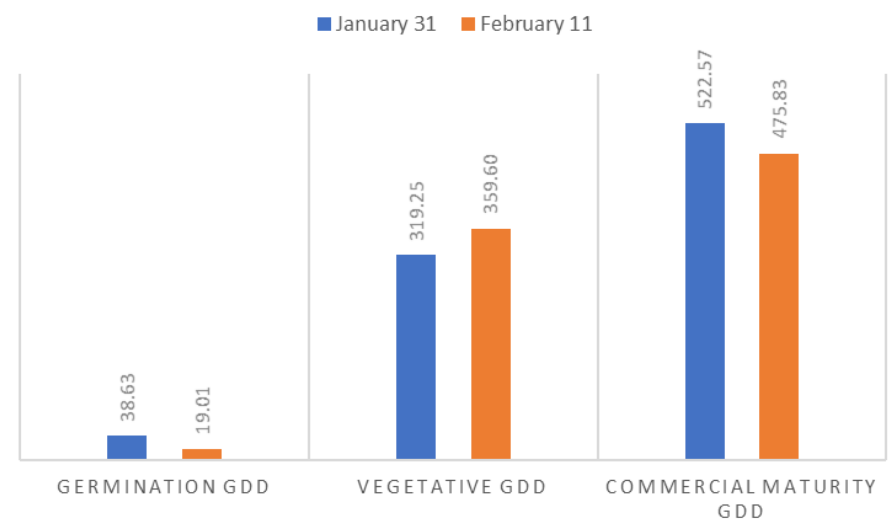

Figure 3. Cumulative degrees-days of development (GDD) in the germination, vegetative and commercial maturity stage that Vincent Choice Dark Eye requires for cut flower of two sowing dates.

Table 2. Phenological stages of sunflower 'Vincent Choice Dark Eye' for cut flower on two sowing dates.

\begin{tabular}{|l|c|c|c} 
Sowign date & $\begin{array}{c}\text { Germination } \\
\text { (Days) }\end{array}$ & $\begin{array}{c}\text { Vegetative } \\
\text { (Days) }\end{array}$ & $\begin{array}{c}\text { Commercial } \\
\text { maturity } \\
\text { (Days) }\end{array}$ \\
\hline January 31 & 5 & 41 & 62 \\
\hline February 11 & 3 & 43 & 54 \\
\hline
\end{tabular}


the cabbage looper worm (Trichoplusia ni, Figure $4 b$ ), and the leaf miner fly (Liriomyza sp., Figure $4 c$ and $4 \mathrm{~d}$ ) were present. To control whiteflies, three weekly application of Roma ${ }^{\circledR}$ detergent at $3 \%$ were carried out.

The cabbage looper worm is a voracious pest that can consume up to three times its own weight daily. The leaf miner flies create tunnels in the leaves. Damage from the pests results in poor and delayed plant development, which compromised its commercial value. Control of the leaf miner and cabbage looper was done through monitoring and manual control, which was a highly efficient practice at lowering the incidence of both pests.

\section{Flowering stage}

Flowering is induced by water stress, without modifying temperature and light conditions (Florido and Bao, 2014). In the January 31 sowing, when the sunflowers reached commercial height, irrigation was reduced by $30 \%$ to induce flowering (Figure 5).

\section{Commercialization}

As part of the study, before beginning the sunflower cultivation, local commercial prices were scouted. In the Texcoco market, the price of ten sunflowers was \$45.00 MX (US\$2.00). In wholesale markets, ten ornamental sunflowers with similar characteristics to the Vincent Choice were priced at \$40.00 MX (US\$1.7). However, at the dates of sale, the price was $\$ 10.00$ MX per ten sunflowers (US\$0.40). The strategies used to raise the sale price was to give added value with wrappings and colored ribbons that showcased the sunflowers' color, reaching a price of \$50.00 MX (US\$2.20) per ten (Figure 6)

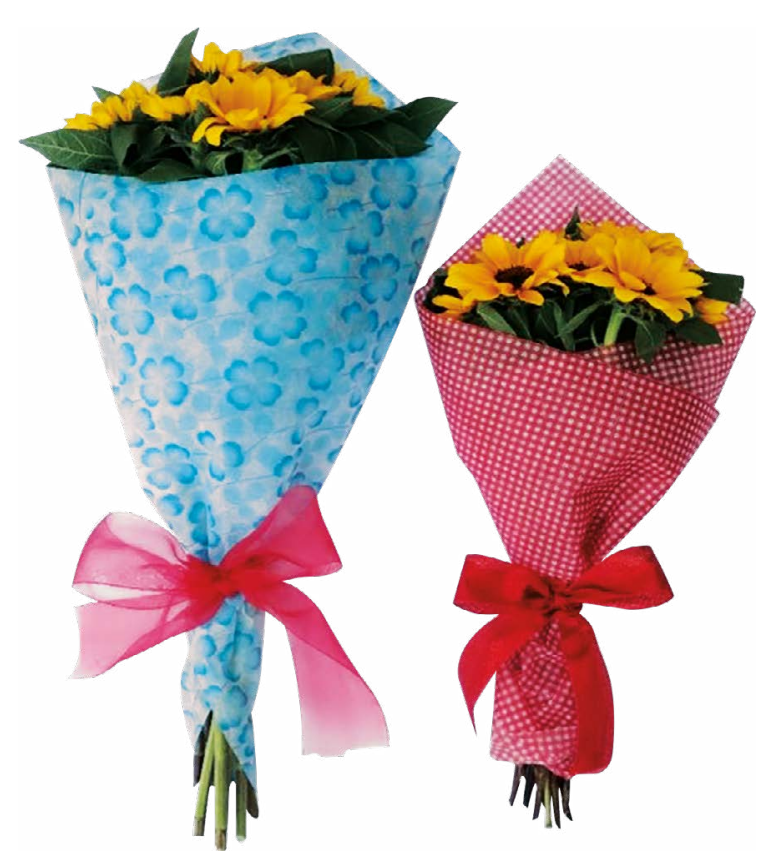

Figure 6. Commercial presentation of the sunflower cut flower.
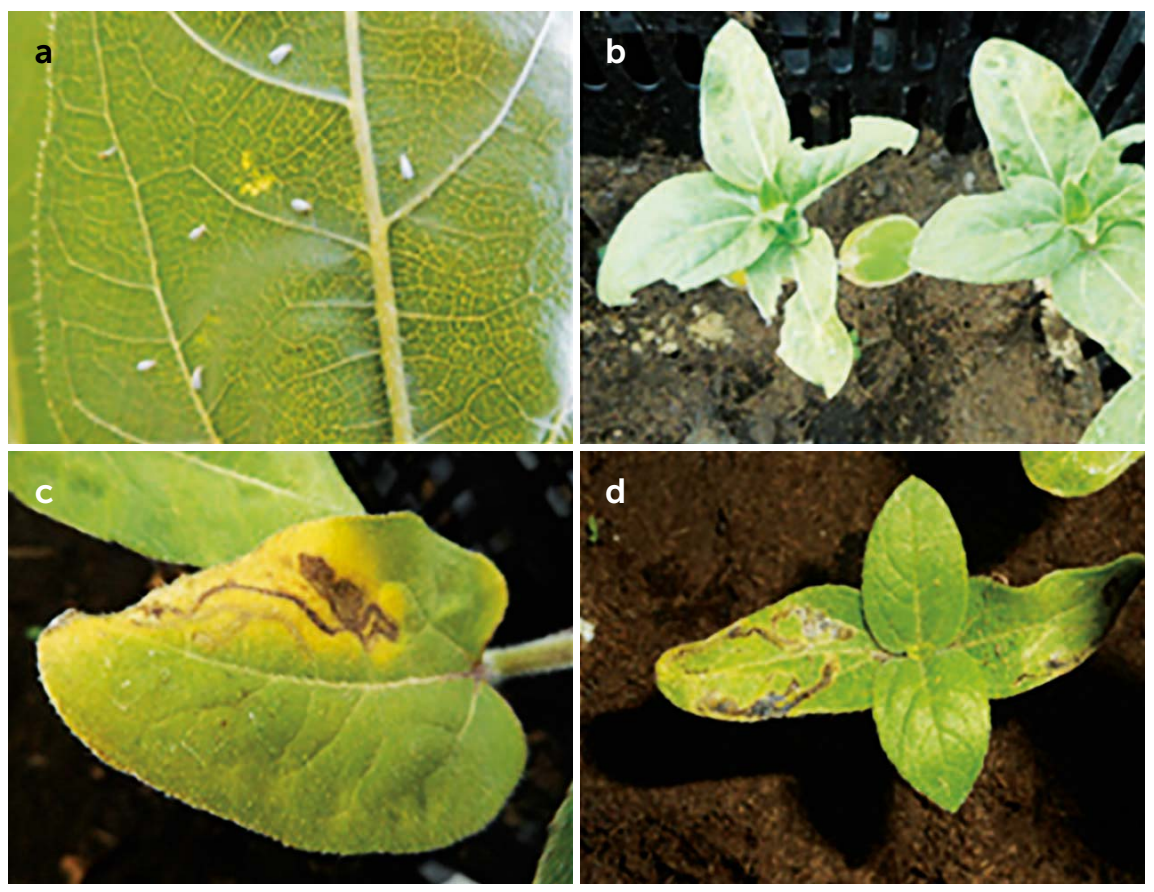

Figure 4. Damage caused by pests on sunflower: (a) white fly, (b) cutworm, (c) and (d) leafminers.

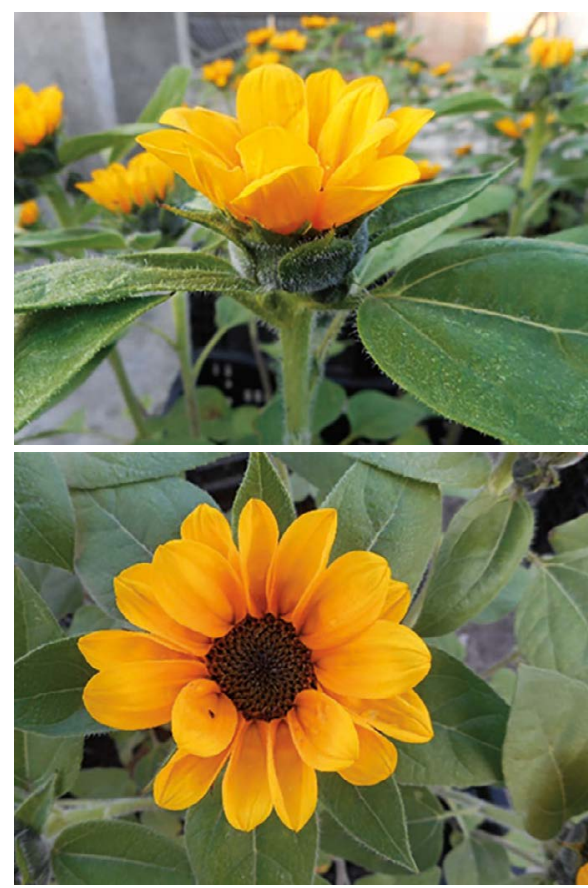

Figure 5. Sunflower cut point 'Vincent Choice Dark Eye' 
This study calculated the costs and profits of cultivating 40 bouquets with ten cut flowers, with a price of $\$ 50.00$ MX (US\$2.20) per bouquet, considering a scenario of 100\% successful sales (Table 3).

The substrate represented $7 \%$ of production costs, but this can be reutilized after disinfecting. The experiment demonstrated an estimation of costs and profits generated in the production and commercialization of cutting sunflowers, resulting in $28 \%$ earnings of gross profit (without cash flow analysis). The production and commercialization of ornamentals is considered to be a profitable business for producers, as long as good production practices are used. Nonetheless, costs should be adjusted for a real commercial production system.

\section{CONCLUSIONS}

At a planting density of 153 plants $\mathrm{m}^{-2}$, the quality of the cutting flowers is maintained. Late sowing increased the height and diameter of the flower. For the sowing date of January 31, the sunflower hybrid required 523 GDD to reach cutting point, and 476 GDD for February 11. The commercialization of sunflower benefitted from the added value, as this increased its market price fivefold.

\section{ACKNOWLEDGEMENTS}

We thank the National Board of Science and Technology for the grant given for Master's degree studies at Colegio de Postgraduados.

\section{REFERENCES}

Alba, A., \& Llanos, M. (1990). El cultivo del girasol. Madrid, España: Mundi-Prensa.

Alberio, C., Izquierdo, N. G., \& Aguirrezábal, L. A. N. (2015). Sunflower Crop Physiology and Agronomy. En Martínez-Force, E., Dunford, N. T., y Salas, J. J. (Eds.), Sunflower (pp. 53-91). Urbana, E.U.: AOCS Press. doi: 10.1016/B978-1-893997-94-3.50009-X

Andrew, R. L., Kane, N. C., Baute, G. J., Grassa, C. J., \& Rieseberg, L. $H$. (2013). Recent nonhybrid origin of sunflower ecotypes in a novel habitat. Molecular Ecology, 22(3), 799-813. doi: 10.1111/ mec.12038

Baghdadi, A., Halim, M., Nasiri, A., Ahmad, I., \& Aslani, F. (2014). Influence of plant spacing and sowing time on yield of sunflower (Helianthus annuus L.). Journal of Food Agriculture and Environment, 12(2), 688-691. Recuperado de https:// www.researchgate.net/publication/263279191_Influence_of_ plant_spacing_and_sowing_time_on_yield_of_sunflower_ Helianthus_annuus_L

Balalić, I., Zorić, M., Brankovic, G., Terzić, S., \& Crnobarac, J. (2012) Interpretation of hybrid $\times$ sowing date interaction for oil content and oil yield in sunflower. Field Crops Research, 137. 70-77. doi: 10.1016/j.fcr.2012.08.005

Bye, R., Linares, E., \& Lentz, D. L. (2009). México: Centro de origen de la domesticación del girasol. TIP Revista Especializada en Ciencias

\begin{tabular}{|c|c|}
\hline Concept & Cost (\$) \\
\hline $\begin{array}{l}\text { Black plastic nursery crates (12 boxes) 5-year } \\
\text { depreciation }\end{array}$ & $888.00 / 5=177.00$ \\
\hline Sunflower seed Vincent Choice Dark Eye & 461.70 \\
\hline Peat moss ( $\$ 700 \times 170 \mathrm{~L})$ & 107.00 \\
\hline Triple fertilizer 18 (1 kg) & 29.00 \\
\hline Detergent Roma & 5.00 \\
\hline Korean paper & 121.50 \\
\hline Colored ribbon & 90.00 \\
\hline Labor cultivation, cutting and packaging (24 h) & 450.00 \\
\hline Grand total & 1441.2 \\
\hline $\begin{array}{l}\text { Gross unit=bundle of sunflowers for sale } \\
40 \times \$ 50.00\end{array}$ & $2,000.00$ \\
\hline Net Unit (Profit) & 558.80 \\
\hline Cost benefit ratio & 1.38 \\
\hline
\end{tabular}

Source: Own elaboration.

Químico-Biológicas, 12(1), 5-12. Recuperado de http://www. scielo.org.mx/pdf/tip/v12n1/1405-888X-tip-12-01-5.pdf

Da Silva, S., Beckmann, M., de Souza, G., de Oliveira, T., Lima, G., \& Chaves, A. (2018). Growth of ornamental sunflowers in two growing seasons under semiarid conditions. Emirates Journal of Food and Agriculture, 30(5), 381-388. doi: 10.9755/ejfa.2018. v30.i5.1681

Escalante-Estrada, J. A. S., Rodríguez-González, M. T., \& EscalanteEstrada, Y. I. (2015). Acumulación y distribución de materia seca en cultivares de maíz asociados con frijol en clima templado. Revista Mexicana de Ciencias Agrícolas, 1, 139-143. Recuperado de https://www.redalyc.org/pdf/2631/263139243021.pdf

Florido, B. M., \& Bao, F. L. (2014). Tolerancia a estrés por déficit hídrico en tomate (Solanum lycopersicum L.). Cultivos Tropicales, 35(3), 70-88. Recuperado de http://scielo.sld.cu/pdf/ctr/ v35n3/ctr08314.pdf

Hammer, G., Goyne, P., \& Woodruff, D. (1982). Phenology of sunflower cultivars. III. Models for prediction in field environments. Australian Journal of Agricultural Research, 33(2), 263- 274. doi: 10.1071/AR9820263

Qadir, G., Malik, M. A., \& Hassan, F. U. (2007). Growing Degree Days and Yield Relationship in Sunflower (Helianthus annuus L.). International Journal of Agriculture \& Biology, 9(4), 564-568. Recuperado de http://www.fspublishers.org/published_ papers/65304_...pdf

Schneiter, A. A., \& Miller, J. F. (1981). Description of Sunflower Growth Stages. Crop Science, 21(6), 901-903. doi: 10.2135/cropsci1981 $.0011183 \times 002100060024 x$

Servicio de Información Agroalimentaria y Pesquera. (2018). Anuario Estadístico de la Producción Agrícola. https://nube.siap.gob. $\mathrm{m} \times /$ cierreagricola/

Universidad de California. (2017). Metodología para el cálculo de Unidades de Calor diseñada por la University of California, Agriculture and Natural Resourses, empleada en el SIMARBC. http://www.simarbc.gob.mx/descargas/metodologiauc.pdf

Vera-Montenegro, L., \& Chavarría, P. J. (2010). Híbridos de girasol ornamental sometidos a diferentes densidades de siembra. 
Espamciencia, 1(2), 60-64. Recuperado de https://www. researchgate.net/publication/279897963_HIBRIDOS_DE_ GIRASOL_ORNAMENTAL_SOMETIDOS_A_DIFERENTES_ DENSIDADES_DE_SIEMBRA

Zamudio, F. \& Alvarado, A. (1994). Análisis de diseños experimentales con igual número de submuestras. Chapingo, México: Universidad Autónoma Chapingo.

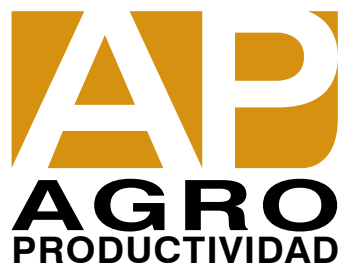

